\title{
8
}

\section{China: The Emerging Superpower}

China's three greatest strengths can be illustratively termed as the 3Ms manpower, manufacturing and market. It was the deft utilization of an abundance of labour supply and a massive market that were the two main attributes with which it was innately endowed that led to the emergence of a competitive and low-cost manufacturing sector.

China's remarkable ascendancy as one of the most important nations in the global economy has been one of the highlights of the preceding two decades. Whether this blend of systems, invariably referred to as one country two systems, is called market-based socialism, neo-Leninism or anything else does not matter significantly, certainly not as much as the ramifications and implications that it has for other developing countries and the world. On a theoretical plane, ideological demarcations become rather ambiguous when we consider the country's rather successful but peculiar combination of communism and market-based economy. China's economic experience does compel a rethink, not just about watertight ideological demarcations (categorical assertions about which will be highly questionable) but also about a wide range of firmly held assumptions related to economic growth, trade, employment and the free market.

Chapters 9-15 will delve into various issues relating to China's economic experience, and the aim once again is to extract from the country's rapid ascent insights and lessons that are applicable to other nations in the developing world. 